\title{
Pengalaman Hidup Wanita Pekerja Seks (WPS) yang Terinfeksi HIV
}

\author{
Alvian Pristy Windiramadhan ${ }^{1}$, Suryani ${ }^{2}$, Kusman Ibrahim $^{3}$ \\ ${ }^{1}$ STIKes Indramayu, Program Studi Sarjana Keperawatan, Jl. Wirapati Sindang - \\ Indramayu, Sindang, Kabupaten Indramayu, Jawa Barat \\ ${ }^{23}$ Universitas Padjadjaran, Fakultas Keperawatan, Jl. Raya Bandung Sumedang \\ KM.21, Hegarmanah, Jatinangor, Kabupaten Sumedang, Jawa Barat \\ Email : alvianpristy28@gmail.com \\ $\begin{array}{ll}\text { Diterima } & : \text { 12 } \text { Oktober } 2020 \\ \text { Disetujui } & : 16 \text { November } 2020 \\ \text { Dipublikasikan } & : \text { 10 Desember } 2020\end{array}$
}

\begin{abstract}
Abstrak
Latar Belakang dan Tujuan: Pada WPS yang terinfeksi HIV, mereka tidak hanya mengalami penderitaan fisik saja, tetapi juga dihadapkan pada penderitaan psikososial akibat adanya stigma dan diskriminasi dari masyarakat. Tujuan penelitian ini untuk mengungkap secara mendalam tentang pengalaman hidup WPS yang terinfeksi HIV sejak pertama kali terdiagnosis HIV, melakukan pengobatan, sampai dengan menjalani kehidupan sehari-hari setelah terinfeksi HIV.

Metode: Desain penelitian yang digunakan adalah kualitatif dengan pendekatan fenomenologi deskriptif. Pengambilan data dilakukan dengan wawancara mendalam pada enam WPS yang terinfeksi HIV yang telah mengungkapkan status dan kondisi penyakitnya kepada petugas kesehatan. Hasil penelitian dianalisis dengan metode Colaizzi.

Hasil: Berdasarkan hasil penelitian pengalaman hidup Wanita Pekerja Seks (WPS) yang terinfeksi HIV dideskripsikan dalam lima tema terkait, yaitu : 1) Merasa tekanan berat, hancur, dan ngedrop ketika tahu status HIV positif, 2) Menerima status, memperoleh dukungan, dan bangkit, 3) Menjalani pengobatan dan berupaya tetap sehat, 4) Berhenti sebegai WPS dan menjalani kesempatan hidup kedua, 5) Jaga diri biar tidak tertular "Corona".

Simpulan dan Implikasi: Kelima tema tersebut dapat diinterpretasikan bahwa makna pengalaman hidup WPS yang terinfeksi HIV adalah dari merasakan keterpurukan saat pertama kali terinfeksi HIV menuju peningkatan kualitas hidup yang lebih baik dalam menjalani aktivitas keseharinya.
\end{abstract}

Kata kunci : Pengalaman hidup; Terinfeksi HIV; Wanita Pekerja Seks

Sitasi: Windiramadhan A P, Suryani \& Ibrahim K. (2020). Pengalaman hidup wanita pekerja seks (WPS) yang terinfeksi HIV.The Indonesian Journal of Health Science. 12(2), 169-182

Copyright: () 2020 Windiramadhan et. al. This is an open-access article distributed under the terms of the Creative Commons Attribution-NonCommercial 4.0 International License, which permits unrestricted use, distribution, and reproduction in any medium, provided the original author and source are credited.

Diterbitkan Oleh: Universitas Muhammadiyah Jember

ISSN (Print): 2087-5053

ISSN (Online): 2476-9614 


\begin{abstract}
Background and Aim: FSWs who are infected by HIV, are not only experiencing physical suffering but also facing psychosocial suffering due to the stigma and discrimination from the community. The purpose of this study is to profoundly uncover the life experiences of FSWs infected by HIV from the time they were first diagnosed with $H I V$, took medication, to lived their daily lives after being infected with HIV.

Methods: This research design employed a qualitative descriptive phenomenological approach. The data were collected by in-depth interviews with six WPS infected with HIV who have revealed the status and condition of the disease to health workers. The results of the study were analyzed by using the Colaizzi method.

Results: Based on the Results the life experiences of female sex workers (FSWs) infected with HIV are described in five related themes i.e.1) Felt under pressure, broken, and dropped out when they know their status HIV positive, 2) Accepted status, gaining support, and rise up, 3 ) Took medication and try to stay healthy, 4) Being stop as FSW and lived a second chance of life, 5) Took care of got infected by "Corona".

Conclusion: The seven themes above can be interpreted that the meaning of life experience of HIV-infected FSWs is from felt depressed when first infected with HIV to improved a better quality of life in carrying out their daily activities.
\end{abstract}

Keywords: Female sex workers; HIV infected; Life experience

\section{PENDAHULUAN}

Era globalisasi saat ini, setiap negara berlomba-lomba untuk membangun peradaban yang lebih baik. Secara umum, pembangunan bertujuan untuk mensejahterakan masyarakatnya. Akan tetapi, dalam proses pembangunan tersebut akan terjadi ketimpangan dalam masyarakat jika banyak individu yang tidak mampu menyesuaikan diri. Hal ini menyebabkan terjadinya perubahan-perubahan dalam diri masyarakat seperti pola perilaku masyarakat yang semakin konsumtif. Perilaku seperti ini memicu timbulnya masalah baru dalam kehidupan masyarakat. Salah satu masalah baru, namun juga dapat dikatakan sebagai masalah lama adalah munculnya prostitusi yang sudah ada sejak berabad-abad lalu (Kartono, 2011).

Prostitusi biasanya dilakukan oleh seseorang atau sekelompok pria ataupun wanita yang sudah berkomitmen untuk menghalalkan cara apapun demi mendapatkan upah atau bayaran. Pekerjaan ini juga bisa disebut dengan pekerjaan instan, sehingga mendorong mereka melakukan penyimpangan sosial. Penyimpangan diartikan sebagai tingkah laku yang tidak sesuai dengan nilai norma ataupun atauran masyarakat. Salah satu bentuk penyimpangan sosial di masyarakat adalah munculnya Wanita Pekerja Seks (WPS) (Kartono, 2011).

Seorang wanita yang bekerja sebagai WPS setiap hari selalu melayani pelanggan yang bergantiganti, bahkan seringkali mendapatkan kekerasan seksual dari pelanggan yang ingin mendapatkan kepuasan dengan melakukan hubungan seksual tanpa menggunakan pelindung ataupun kondom bahkan layanan seks anal (Nelson, 2019). Akibatnya seorang WPS sangat mudah dan rentan sekali terinfeksi penyakit Infeksi Menular Seksual (IMS) bahkan yang lebih parahnya lagi adalah terinfeksi HIV/AIDS. WPS sendiri merupakan kelompok resiko tinggi yang dapat 
tertular HIV/AIDS (Kemenkes, 2018).

HIV/AIDS saat ini merupakan masalah kesehatan yang mengancam Indonesia dan banyak negara di seluruh dunia. HIV merupakan virus yang menyerang atau menginfeksi sel darah yang menyebabkan turunnya kekebalan pada tubuh manusia (Octavianty, Rahayu, Rosadi, \& Rahman, 2015). Konsekuensianya seseorang yang terkena HIV akan sangat mudah sekali terkena berbagai penyakit infeksi (infeksi oportunistik) yang berakibat fatal (Kemenkes, 2018)

Epidemi HIV/AIDS secara global telah memasuki kondisi yang kritis. Data United Nations Programme on HIV/AIDS (UNAIDS) menunjukan bahwa pada tahun 2018 di dunia secara global jumlah kasus infeksi HIV baru sebesar 1,7 juta orang (UNAIDS, 2019). Situasi yang memperihatinkan tersebut juga terjadi pada negaranegara yang sedang berkembang dengan status sosial ekonomi rendah yang diperkirakan setiap harinya ditemukan sebanyak 6.000 kasus HIV pada kelompok usia produktif yaitu antara 15-24 tahun (Kemenkes, 2018).

Data kumulatif kasus HIV di Indonesia sejak ditemukan pertama kali pada tahun 1987 di Bali sampai dengan Juni 2019 telah menyebar di 463 Kabupaten/Kota di seluruh Provinsi di Indonesia dan baru sekitar $60,7 \%$ kasus yang dilaporkan yaitu sebesar 466.859 dari estimasi ODHA tahun 2016 sebanyak 640.443 kasus (Ditjen P2P Kemenkes RI., 2019). Jumlah kasus HIV di Jawa Barat menempati urutan ke tiga setelah DKI Jakarta dan Jawa Timur dengan jumlah kasus sebanyak 35.529 kasus. Peningkatan kasus HIV/AIDS di Jawa Barat bukan hanya ditemukan di kota-kota besar saja. Akan tetapi, kabupaten yang secara geografis letaknya jauh dari kota besar juga ikut menyumbang kasus HIV baru yang cukup tinggi ke-dua yaitu Kabupaten Indramayu.

Data Komisi Penanggulangan AIDS (KPA) Kabupaten Indramayu menyebutkan jumlah kasus HIV/AIDS dari tahun 1993 sampai dengan tahun 2018 sebanyak 3399 kasus. Berdasarkan data Dinas Kesehatan Kabupaten Indramayu (2019), Jumlah WPS yang terinfeksi HIV/AIDS dari tahun 1993 sampai dengan tahun 2018 sebanyak 896 orang positif terinfeksi HIV/AIDS.

Dalam kehidupan sehari-hari, seorang WPS sering kali mendapatkan tekanan dari masyarakat, bahkan menjadi bahan olokan dan ejekan (Kartono, 2011) Sama halnya pada orang dengan HIV/AIDS yang sering mendapatkan stigma dan diskriminasi dari masyarakat. Sehingga fenomena pengalaman WPS yang terinfeksi HIV merupakan hal yang sangat kompleks. Dimana seorang WPS yang terinfeksi HIV beresiko mengalami permasalahan baik secara fisik, psikis, sosial, dan spiritual.

Beberapa penelitian telah banyak mengungkapkan pengalaman hidup orang dengan HIV/AIDS. Namun, masih sedikit ditemukan penelitian yang mengeksplorasi pengalaman hidup WPS yang terinfeksi HIV Berdasarkan fenomena tersebut peneliti tertarik untuk mengungkap secara mendalam pengalaman hidup WPS yang terinfeksi HIV. Meskipun sudah ada beberapa penelitian yang mengungkap pengalaman WPS yang terinfeksi HIV, dengan konteks 
budaya dan situasi yang berbeda akan memberikan pengalaman yang berbeda juga.

\section{METODE PENELITIAN}

Penelitian ini telah mendapatkan rekomendasi persetujuan etik oleh Komisi Etik Penelitian Universitas Padjadjaran Bandung nomor $\quad 374 / \mathrm{UN6}$.KEP/EC/2020. Metode penelitian pengalaman hidup Wanita Pekerja Seks (WPS) yang terinfeksi HIV, peneliti menggunakan pendekatan fenomenologi deskriptif. Pengalaman hidup dalam penelitian ini dibatasi hanya pada pengalaman hidup WPS sejak pertama kali tahu didiagnosis terinfeksi HIV, melakukan pengobatan, sampai dengan menjalani kehidupan sehari-harinya setelah terinfeksi HIV. Partisipan dalam penelitian ini sebanyak enam orang WPS yang terinfeksi HIV yang memenuhi kriteria inklusi berusia 25 - 45 tahun, masih bekerja atau pernah bekerja sebagai WPS lebih dari 1 tahun, lebih dari enam bulan setelah terdiagnosis dan telah mengungkapkan status dan kondisi penyakitnya kepada petugas kesehatan, keadaan umum baik, mampu berkomunikasi, kooperatif dan mau mengungkapkan pengalaman hidupnya

Penelitian ini telah
dilaksanakan pada bulan April - Mei 2020 di Kecamatan X Kabupaten Indramayu yang merupakan kecamatan yang menempati urutan pertama jumlah penderita HIV terbanyak di wilayah Kabupaten Indramayu. Pada saat penelitian berlangsung bersamaan dengan masa Pandemi Covid-19, untuk menjaga keamanan sehingga sebelum menemui partisipan peneliti mengecek kesehatan peneliti terlebih dahulu dengan cara mengecek suhu tubuh dan mengatisipasi penularan Covid menggunakan masker. Saat menemui partisipan peneliti didampingi oleh perawat Puskesmas dan KDS. Peneliti memperkenalkan diri, mengecek kondisi kesehatan partisipan terlebih dahulu, menjelaskan tujuan, prosedur, manfaat, serta etika penelitian. Peneliti juga melakukan physical distancing dengan cara menjaga jarak dengan partispan dan memberikan masker wajah untuk digunakan oleh partisipan selama proses wawancara. Kemudian peneliti melakukan wawancara dengan menggunakan teknik in depth interview selama $30-60$ menit di rumah partisipa dan hasil penelitian dianalisis dengan metode Colaizzi.

\section{HASIL}

Pengalaman hidup Wanita Pekerja Seks (WPS) yang terinfeksi HIV dideskripsikan dalam 5 tema terkait, yaitu 1) Merasa tekanan berat, hancur, dan ngedrop ketika tahu status HIV positif, 2) Menerima status, memperoleh dukungan, dan bangkit, 3) Menjalani pengobatan dan berupaya tetap sehat, 4) Berhenti sebegai WPS dan menjalani kesempatan hidup kedua, 5) Jaga diri biar tidak tertular "Corona"

\section{Tema 1 : Merasa tekanan berat, hancur, dan ngedrop ketika tahu status HIV positif}

Tema ini diperoleh dari
pengalaman partisipan yang
mengungkapkan mengenai
perasaanya dan kondisnya fisiknya
pada saat pertama kali tahu bahwa
dirinya positif terinfeksi HIV. Tema
ini terdiri dari tiga sub tema yaitu
merasakan tekanan berat, hatinya


merasa hancur, dan kondisi tubuhnya ngedrop.

Sub tema merasakan tekanan berat diungkapkan partisipan akibat merasa tidak ada harapan, mengalami stress, berpikir HIV penyakit yang menakutkan, merasa dijauhi serta dibicarakan orang lain. Hal tersebut didukung oleh pernyataan partisipan sebagai berikut:

P1 :"Ya wis langka harapan, pasti bakalan mati mikire kuh. Sedurunge mah ya durung weruh HIV kuh priben-pribene mah, cuman weruhe ya baka wis positif HIV kuh penyakit sing pasti bakale mati. Soale ya wis akeh batur-batur ning kene gah sing positif HIV terus pada mati. (Ya sudah tidak ada harapan, pasti bakalan mati mikirnya tuh Sebelumnya sih ya belum tahu HIV tuh gimana-gimananya sih, cuman tahunya ya kalau sudah positif HIV tuh penyakit yang pasti akan meninggal. Soalnya ya sudah banyak teman-teman disini juga yang positif HIV terus pada meninggal.)"

Sub tema kedua diungkapkan partispan akibat merasa tidak menyangka, merasa malu, hancur, merasakan kesedihan, dan timbul perasaan menyesal saat pertama terinfeksi HIV. Hal tersebut didukung oleh pernyataan partisipan sebagai berikut:

P4 : "Ya pengalaman saya waktu itu ya down hancur banget sampe ngedrop. Sampe ga mau mikirin makan ga mau, sampe 2 bulan ga mau makan, ga mau minum, nangis terus mikirin nasib saya."

P2 : "Ya awale mah kaget lah...Kaya ora anu kah ora nerima kah, ya priwe maning sih wong maune kitane kerja mengkonon orah. (Ya awalnya sih kaget lah... seperti itu tuh... tidak menerima tuh, ya gimana lagi sih kan tadinya sayanya kerja begitu kan.)"

Sub tema ketiga diungkapkan partisipan yang merasa kondisinya ngedrop dan mulai dirasakan gejala klinis seperti demam, gatal-gatal, sesak nafas, keputihan, diare berkepanjangan, keputihan, dan sariawan yang tidak kunjung sembuh pada saat pertama terinfeksi HIV. Hal tersebut didukung oleh pernyataan partisipan sebagai berikut:

P1 : "Pertama mah diare, mangan kien jlarat bae, panas dingin, sariawan ora mari-mari, kan sing diserangkan tentara tubuhe ora ya? Dadi lemah, dadie gering gering terus, darahe turun, panas dinginie lebihi panas dingine biasa, seminggu ora mari-mari. (Pertama sih diare, makan ini keluar terus, panas dingin, sariawan tidak sembuh-sembuh, kan yang diserang itu tentara tubuhnya kan? Jadi lemah, jadinya sakitsakitan terus, darahnya turun, panas dinginnya melebihi panas dingin biasa, seminggu tidak sembuhsembuh)"

P3 : "Awalnya yang dirasa sih gatelgatel, kaya ada luka begitu, terus badan lemes banget, demam.... Ya ngedrop banget."

P2 : "Awale kuh baka arep magrib kuh awake panas bae, terus bari nafase sesek kah. (Awalnya tuh kalau mau magrib, badan panas terus, terus juga nafasnya sesek tuh.)"

$\begin{aligned} & \text { Tema 2 : } \\ & \text { memperoleh } \\ & \text { bangkit } \\ & \text { dukungan, }\end{aligned}$
$\begin{aligned} & \text { Tema ini diperoleh } \\ & \text { dan }\end{aligned}$
$\begin{aligned} & \text { dari } \\ & \text { menyataan partisipan }\end{aligned}$
$\begin{aligned} & \text { yang } \\ & \text { membuka diri, menerima dirinya }\end{aligned}$


sebagai ODHA, mendapatkan dukungan dari orang sekitarnya, dan bangkit dari masalah yang dihadapinya. Tema ini terdiri dari tiga sub tema, yaitu : menerima status dirinya sebagai ODHA, mendapatkan dukungan, dan bangkit.

Sub tema yang pertama mengungkapkan bagaimana WPS yang tetrinfeksi HIV berproses menerima dirinya sebagai ODHA dengan menceritakan status HIVnya pada pasangannya, menceritakan status HIV pada keluarganya, membuka diri, perasaannya yang merasa biasa saja, sudah bisa menerima, tidak peduli orang lain mengetahui dirinya positif HIV, dan mampu menjalani aktivitas kembali. Hal tersebut didukung oleh pernyataan partisipan sebagai berikut:

P4 : "Saya mah waktu awal tahu positif kan langsung bilang pa sama keluarga tuh begitu pulang dari penampungan Taiwan itu. Jadi keluarga ya langsung mendukung pengobatan aja"

P5 : "Keluarga di paih weruh, terus ora menutup diri karo tangga yen kita kuh positif HIV. Ya walaupun awal-awale memang angel sih, tapi ya sue-sue kuh biasa bae. (Keluarga dikasih tahu, terus tidak menutup diri sama tetangga kalau saya tuh positif HIV. Ya walaupun awal-awalnya memang susah sih, tapi ya lama-lama biasa saja"

Sub tema yang kedua mengungkapkan bagaimana orang lain disekitarnya seperti keluarga, teman, tetangga, dan masyarakat memberikan dukungan untuk tetap sehat dengan menjalani pengobatan secara teratur setelah dirinya terinfeksi HIV. Hal tersebut didukung oleh pernyataan partisipan sebagai berikut:
P1 : “...Olih support sing keluarga, batur-batur, maih semangat intine mah, dadi intine mah ohhhh kita kuh ora dewekan, akeh bature (...Dapat support dari keluarga, teman-teman, memberikan semangat intinya sih, jadi intinya sih ohhhh saya tuh tidak sendiri, banyak temannya

P3 : “...Didukung sama orang tua. Ya saudara-saudara juga kan pada sayang sama saya. Engga menghindarlah dari saya tuh. Jadi membuat saya semangat. Jadi mau berobat."

Sub tema yang ketiga mengungkapkan bagaimana partisipan memotivasi dirinya untuk tetap sehat dan mampu menjalani aktivitasnya kembali setelah dirinya terinfeksi HIV.

P1 : "Ya deleng batur, contohe kuh batur. ohhhh kuen bae gah bisa sehat, apa maning kita?(Ya melihat teman, mencontohnya tuh teman. Ohhhh itu saja juga bisa sehat, apa lagi saya?)"

P4 : "Saya mah kan begitu pulang dari penampungan tuh, terus lamalama tuh berpikir kalo saya begini terus, lantas bagaimana nasib anak saya yang masih kecil, masih butuh perhatian, jadi tuh timbul keinginan untuk sembuh, untuk bangkit dari keterpurukanlah

\section{Tema 3 : Menjalani pengobatan dan berupaya tetap sehat}

Pada tema ini terdiri dari dua sub tema, yaitu : melakukan pengobatan dan berupaya untuk tetap sehat. Tema ini diperoleh dari pernyataan partisipan yang mengungkapkan bagaimana dirinya menjalani pengobatan pada saat awal terinfeksi HIV sampai dangan upaya yang dilakukan agar kondisnya tetap sehat. 
Sub tema yang pertama diungkapkan bagaimana partisipan mencari akses layanan kesehatan setelah terinfeksi HIV, menjalani konseling, dan merasakan efek samping pengobatan ARV. setelah terinfeksi HIV. Hal tersebut didukung oleh pernyataan partisipan sebagai berikut:

P3 : "Pertama kan ke puskesmas, terus karena kondosinya ngedrop, terus karena tahu kena penyakit HIV jadi tuh dirujuk ke rumah sakit. Alhamdulilah sih ga ada kendala, sampe sekarang juga menjalani pengobatan juga kalo ke rumah sakit ga ada kendala. Paling ya karena lumayan jauh ya, kalo mau kerumah sakit harus berangkatnya pagi-pagi biar ga ngantri lama."

P1 : "Ya sedurung dipaih obat kan di konseling dipit pa, terus dipaih obat ARV karo dijelas aken efek sampinge mengkenen-mengkenen, kita mah lagi awal-awal kan nginung cotri ya langka keluhan, nah pas nginung Evapirenz pa sing kerasa gliyengan kaya wong mabok kah. (Ya sebelum dikasih obat kan dikonseling dulu pa, terus dikasih obat ARV sama dijelaskan efek sampingnya beginibegini, saya sih waktu awal-awal kan minum cotri ya ga ada keluhan, nah pas minum Evapirenz pa yang terasa gliyengan seperti orang mabok tuh.)"

Sub tema kedua diungkapkan partisipan dengan berupaya untuk tetap sehat dan melakukan pengobatan alternatif. Adapun ungkapan beberapa partisipan terkait sub tema ini dapat dilihat dibawah ini :

P4 : "Pernah pa, saya mah minum rebusan sambiloto, godong joar, sampe kunir. Sekarang juga masih suka minum, tapi ga tiap hari kaya minum ARV tuh pa. itu mah kadang seminggu dua kali. Itu juga saya tahu tuh dari temen-temen yang senasib dengan saya. Kan kalo berobat ngantrinya lama ya, jadi kita saling sharing informasi satu sama lain. Terus ada yang bilang "minum jamu ini, minum itu" (menirukan perkataan temannya). Kan intinya sih pengen sehat ya pa, jadi ya di coba saja, kan ini mah bahannya herbal, terus yang buatnya kan sendiri juga.."

\section{Tema 4 : Berhenti sebagai WPS dan menjalani kesempatan hidup kedua}

Tema ini terdiri dari dua sub tema, yaitu : berhenti bekerja sebagai WPS dan merasakan kesempatan hidup yang kedua untuk hidup lebih baik. Tema ini diperoleh dari pernyataan partisipan yang mengungkapkan perubahan perilaku seksual dan perubahan kehidupannya setelah terinfeksi HIV.

Sub tema yang pertama diungkapkan partisipan yang memutuskan untuk berhenti bekerja menjadi WPS karena kondisinya yang lemah setelah terinfeksi HIV.

P1 : "Ya langsung marian kerjae pa, wong lagi kuen kan kondisi tubuhe kan lagi ngedrop. Boro-boro arep ngelayani tamu, dandan sing ayu, arep tangi bae gah kosi angel pisan. Awak kosi tinggal balung karo kulit bae, katon kurus pisan.(Ya langsung berhenti kerjanya pa, pada saat itu kan kondisinya sedang ngedrop. Boro-boro mau melayani tamu, dandan yang cantik, mau berdiri saja susah sekali. Badan tinggal tersisa tulang sama kulit saja, kelihatan kurus sekali"

Sub tema yang kedua diperoleh dari pernyataan partisipan yang mengungkapkan makna hidupnya saat ini setelah terinfeksi HIV. Mereka mengungkapkan bahwa 
setelah terinfeksi HIV seperti mendapatkan kesempatan hidup yang kedua dan merasa hidupnya jauh lebih baik. Adapun ungkapan beberapa partisipan terkait sub tema ini dapat dilihat dibawah ini :

P4 : "Saya sih memaknainya sebagai kesempatan saya untuk berubah lebih baik, lebih berguna untuk orang banyak terutama setelah saya bergabung menjadi KDS di Bhayangkara, memberikan support untuk orang lain, orang yang statusnya sama seperti saya untuk tetap kuat, untuk bangkit dari keterpurukan dan menjalani kehidupan yang lebih berkualitas."

\section{Tema 5 : Jaga diri biar tidak tertular "Corona"}

Tema ini diperoleh dari pernyataan partisipan yang mengungkapkan bagaimana WPS yang terinfeksi HIV menjalani kegiatannya di masa pandemi Covid19. Tema ini terdiri dari dua sub tema yaitu tetap menjalani pengobatan dam

Sub tema pertama diungkapkan oleh partisipan dengan tetap menjalani pengobatan ARV walaupun dimasa pandemi Covid-19. Adapun ungkapan partisipan terkait sub tema ini dapat dilihat dibawah ini :

P6 : "Sekien mah ya pada bae sih. Berobat sebulan sepisan, stok obat ya cukup. Terus ning kana baka ngemet obat diwarahi kokon selalu ngango masker jeh, sering cuci tangan, hindari kontak fisik, menghindari kerumunan. (Sekarang sih ya sama saja sih. Berobat sebulan sekali, stok obat juga cukup. Terus disana juga kalau ambil obat dikasih tahu suruh selalu pakai masker, sering cuci tangan, hindari kontak fisik, menghindari kerumunan" $\begin{array}{ccr}\text { Sub tema yang } & \text { kedua } \\ \text { diungkapkan } & \text { partisipan } & \text { dengan } \\ \text { mendapatkan } & \text { edukasi } & \text { tentang }\end{array}$ pencegahan penularan covid saat melakukan pengobatan dimasa pandemi Covid 19. Adapun ungkapan a partisipan terkait sub tema ini dapat dilihat berikut ini:

P3 : "Ya paling itu sih disuruh selalu pakai masker kalo keluar rumah, rajin mencuci tangan, jauhi keramaian, terus jangan pergi ke daerah-daerah yang banyak virus coronanya seperti Jakarta, Bandung, ya itu aja sih. Kemaren juga pas ngambil obat di rumah sakit diajarinnya begitu sama petugasnya."

P4 : "Saya sih menjalaninya sama saja seperti biasa, dirumah sebagai ibu rumah tangga beres-beres rumah, ngurusin anak, ngurusin suami, kalau hari selasa dan kamis ke rumah sakit, ikkut membantu mendampingi temen-temen ODHA yang lain. Yang peting sekarang mah harus jaga diri aja biar ga tertular virus corona, dengan selalu pakai masker, cuci tangan teratur, dan pola hidup sehat"

\section{PEMBAHASAN}

WPS yang terinfeksi HIV tidak hanya mengalami kesehatan fisik akibat munculnya gejala penyakit, akan tetapi mereka juga mengalami tekanan batin saat pertama kali positif terinfeksi HIV. Menurut Kubler Ross (1969) dalam Videbeck (2011) seseorang yang berduka ataupun kehilangan akan melewati lima tahapan yakni, tahap denial, anger, bargainning, depression, dan acceptance. Artinya ketika WPS yang terinfeksi HIV muncul reaksi emosional berupa kesedihan, tidak menyangka, stress, terpuruk dan 
sebagainya merupakan hal yang lumrah atau wajar pada seseorang yang tahu terdiagnosis suatu penyakit. Hal sama juga diungkapkan Shaluhiyah \& Priyadi, (2018) yang mengungkapkan bahwa respon saat pertama kali mengetahui bahwa dirinya terinfeksi HIV positif menolak terhadap status HIV positif respon nya kaget,terkejut,dan tidak percaya meluapkan perasaan emosional dalam bentuk stress dan depresi.

Tekanan berat yang lainnya diungkapkan dengan dijauhi dan dibicarakan orang-orang sekitarnya, akibat penyakit HIV dan pekerjaanya yang dulu sebagai WPS. Secara sosial, WPS yang terinfeksi HIV sering kali mendapatkan stigma dan diskriminasi dari keluarga, teman, rekan kerja maupun masyarakat sekitar. Stigma diartikan sebagai lebel sosial yang dapat mengubah cara pandang seseorang terhadap diri sendiri. Stigma dikaitkan dengan pemberian label yang berbeda dan bersifat negatif, sedangkan diskriminiasi mengarah pembedaan perlakuan (Karamouzian, Akbari, Haghdoost, Hamidreza Setayesh, \& Zolala, 2014).

Menurut penelitian dilakukan Hargreaves et al. (2017) tentang tumpang tindih stigma HIV dan bekerja menjadi pekerja seks di antara WPS di seluruh Zimbabwe. Hasilnya menunjukan bahwa stigma terinfeksi HIV akan lebih tinggi ketika bekerja sebagai WPS. Hal ini menyebabkan WPS yang terinfeksi HIV merasa malu, kehilangan rasa hormat atau harga diri, dibicarakan dengan buruk, diserang secara verbal, dan merasakan penolakan layanan oleh petugas kesehatan ketika positif HIV karena bekerja menjadi WPS. Hal ini sejalan dengan penelitian yang dilakukan Carsita (2017) yang bertujuan untuk mengekplorasi pengalaman ODHA dalam menghadapi stigma dan diskriminasi terkait penyakitnya, mereka merasakan orang yang ada disekitarnya menghindar akibat menderita penyakit yang dianggap sebagai penyakit yang menakutkan sehingga menyebabkanreaksi respon emosi negatif.

Penderitaan batin juga dirasakan WPS yang terinfeksi HIV melalui perasaan tidak berdaya yang dinyatakan dengan perasaan pasrah dan tidak ada harapan. Mereka mengungkapkan bahwa penyakit HIV AIDS membuat mereka berpikir bahwa hidup mereka akan berakhir. Menurut penelitian Leyva-Moral et al., (2015) ODHA mengalami perasaan tidak berharga dan putus asa yang berasal dari pikiran ODHA sendiri yang menganggap bahwa mereka sebentar lagi akan menghadapi kematian setelah didiagnosa HIV AIDS.

Selain masalah psikososial, masalah fisik juga terganggu. Hal ini di ungkapkan oleh partisipan yang merasa dirinya ngedrop setelah positif terinfeksi HIV. Menurut Nursalam dan Kurniawati (2009) pada tahapan infeksi HIV primer orang yang baru terinfeksi HIV sering menunjukkan sindrom retroviral akut. Tanda dan gejala retroviral akut meliputi panas, nyeri otot, sakit kepala, mual, muntah, diare, berkeringkat di malam hari, kehilangan berat badan dan timbul ruam. Tanda dan gejala tersebut biasanya akan muncul kemudian menghilang setelah beberapa hari sehingga sering dianggap sebagai influenza.

Setelah muncul masalah psikologis dan masalah fisik saat 
pertama kali terinfeksi HIV. Pada tahap selanjutnya WPS yang terinfeksi HIV yang survive mnejalani kehidupannya akan masuk ke tahap acceptance. Menurut Kubler Ross (1969) dalam Videbeck (2011) seseorang yang berduka ataupun kehilangan, akan masuk pada tahapan akhir setelah melewati empat tahapan sebelumnya yaitu pada tahap penerimaan. Penerimaan (acceptance) terjadi bila seseorang mampu menghadapi kenyataan dari pada hanya menyerah pada tidak adanya harapan.

Membuka diri atau selfdisclosure umumnya dilakukan oleh ODHA dengan mempertimbangkan keuntungan dan kerugian dari selfdisclosure tersebut. Keuntungan selfdisclosure telah banyak diungkapkan di antaranya membantu ODHA memperoleh dukungan, kesehatan fisik dan mental yang lebih baik, dan meningkatkan kepatuhan terhadap pengobatan ARV (Stutterheim et al., 2016). Menerima status dirinya sebagai ODHA dirasakan oleh WPS yang terinfeksi HIV setelah melakukan self-disclosure. Perasaan menerima dirinya sebagai ODHA ini diungkapkan sebagai perasaan bisa menerima kenyamanan batin dirasakan oleh ODHA dengan merasakan kelegaan hati (Gillard \& Roark, 2013).

Penerimaan diri sangat dipengaruhi oleh dukungan sosial yang berasal dari lingkungan keluarga yang sangat efektif diberikan pada ODHA, karena sesuai dengan nilai, norma, dan keyakinan dalam keluarga sehingga mudah untuk diberikan setiap saat (Koentjoro, 2004). Di samping itu ODHA juga membutuhkan penerimaan dari lingkungan yang lebih luas dari masyarakat seperti teman, tetangga, tenaga kesehatan, dan kelompok dukungan untuk mengurangi depresi, isolasi sosial, kepatuhan pengobatan, dan sebagai sumber koping (Karamouzian et al., 2014)

Saat ini pengobatan utama penyakit HIV/AIDS adalah dengan menggunakan terapi antiretroviral (ARV) dan merupakan satu-satunya pengobatan HIV/AIDS. Prinsip utama penggobatan ARV hanya untuk mengendalikan replikasi virus, tidak dapat membunuh virus HIV (Ditjen P2P Kemenkes RI., 2019). Konseling sangat diperlukan untuk pasien yang menjalani pengobatan seumur hidup, karena diperlukan pemahaman yang baik tentang manfaat obat dan dampak yang muncul apabila tidak patuh menjalani pengobatan (Kusuma, 2013). Thompson, Havenga, dan Naude (2015) mengungkapkan bahwa saat ini ODHA rutin menjalani pengobatan setelah memperoleh informasi tentang penyakit HIV/AIDS dari petugas kesehatan. Selain itu, pemberian informasi mengenai efek samping pengobatan juga membantu ODHA mengembangkan strategi untuk mengelola efek samping.

Pada WPS yang terinfeksi HIV, mereka memutuskan untuk berhenti bekerja sebagai WPS dan melakukan pencegahan penularan HIV dengan cara meninggalkan perilaku berisiko dan setia dengan pasangannya. Mereka juga memaknainya sebagai kesempatan hidup kedua. Menurut Bastaman (1993) dalam Rahakbauw (2016) Individu mampu mengubah dirinya dari pengalaman tidak bermakna (meaningless) menjadi bermakna (meaningfull), bahkan tidak sedikit yang berhasil menemukan hikmah 
dari penderitaannya (meaning in suffering). Upayaupaya pribadi yang mengatasi penderitaan adalah cara dalam menemukan makna hidup (the meaning of life) serta mengembangkan hidup secara bermakna (the meaningfull life).

Hal ini mereka lakukan dengan menganggap bahwa cobaan atas penyakit HIV ini adalah yang membawa mereka untuk merasakan hidup yang lebih baik. Setelah sebelumnya merasakan sebagai wanita malam, wanita yang selalu berganti-ganti pasangan, dan wanita yang kehidupannya kelam. Seperti dalam Al-Quran surat Ar-Ra'd ayat 11 yang berbunyi :

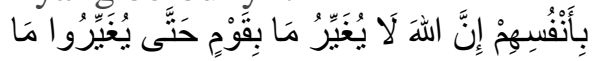

$$
\begin{aligned}
& \text { "Sesungguhnya Allah tidak }
\end{aligned}
$$

mengubah keadaan sesuatu kaum sehingga mereka mengubah keadaan yang ada pada diri mereka sendiri."

Pengalaman hidup yang lainnya adalah pada saat WPS yang terinfeksi HIV menjalankan kehiduapnnya dimasa pandemi Covid-19. Walaupun pada ODHA yg positif Covid-19 secara global angkanya masih belum secara pasti,. Menurut UNAIDS (2020) semua orang, termasuk orang yang hidup dengan HIV, harus mengambil tindakan pencegahan yang direkomendasikan untuk mengurangi pajanan terhadap Covid-19.

Menurut penelitian yang dilakukan Chenneville, Gabbidon, Hanson, \& Holyfield (2020) ODHA yang penyakitnya tidak dikelola dengan baik ditempatkan pada peningkatan risiko untuk tertular dan mengalami komplikasi terkait dengan COVID-19, selain komplikasi terkait dengan perkembangan penyakit HIV seperti munculnya infeksi oportunistik. Mengingat prognosis HIV seumur hidup, maka penting bagi ODHA untuk secara teratur mengunjungi penyedia layanan kesehatan mereka dan mematuhi pengobatan ARV. Di masa pandemi Covid-19 ini, tentunya akan berpengaruh pada pengobatan yang dilakukan oleh ODHA.

Dari hasil penelitian didapatkan bahwa partisipan tetap menjalani aktivitasnya sebagai ODHA dimasa pandemi Covid-19. WPS yang terinfeksi HIV mereka mengungkapkan bahwa tetap menjalani pengobatan ARV dan melakukan pemeriksaan CD4. Mereka juga menjelaskan bahwa dalam pelaksanaan pengobatan selama pandemi Covid-19 dari managemen rumah sakit mengeluarkan kebijakan khusus untuk pasien anak, pengambilan obat bisa diwakilkan oleh orang tuanya, sedangkan untuk ODHA yang kesulitan mengakses kerumah sakit pengambilan obat bisa dibantu oleh KDS dan obat akan dikirimkan dengan paket ekspedisi. Selain itu pula selama masa pandemi Covid-19 saat melakukan pengobatan, mereka mendapatkan edukasi tentang pencegahan Covid-19 dari petugas kesehatan, sehingga dalam melakukan aktivitasnya mereka menerapkan pencegahan penularan Covid-19.

Pencegahan penularan Corona ini dilakukan dengan menerapkan protokol kesehatan. Hal ini dilakukan beberapa prinsip yang perlu diikuti untuk membantu mencegah Covid19 (Kemenkes, 2020). ODHA yang mengetahui status HIV mereka disarankan untuk mengambil tindakan pencegahan yang sama seperti populasi umum, seperti : sering mencuci tangan sering, etika batuk, hindari menyentuh wajah, menjaga jarak, mencari perawatan 
medis jika bergejala, isolasi diri jika kontak dengan seseorang dengan COVID -19 dan tindakan lain sesuai rekomendasi yang dianjurkan oleh pemerintah). Selain itu untuk ODHA yang menggunakan obat-obatan ARV harus memastikan bahwa mereka memiliki paling sedikit 30 hari stok ARV jika suplai 3 sampai 6 bulan tidak tersedia dan memastikan bahwa status vaksinasi mereka diperbaharui (vaksin influenza dan pneumokokus) (WHO, 2020).

\section{Keterbatasan Penelitian}

WPS yang terinfeksi HIV yang berpartisipasi dalam penelitian ini merupakan WPS yang sudah bangkit dari keterpurukannya dan rutin menjalani pengobatan. Hal ini tentunya memiliki perbedaan ketika WPS yang terinfeksi HIV yang ikut serta dalam penelitian merupakan WPS yang masih aktif bekerja dan belum membuka diri kepada keluarga, petugas kesehatan, serta rutin menjalani pengobatan.

\section{SIMPULAN}

Pengalaman hidup Wanita Pekerja Seks (WPS) yang terinfeksi HIV dideskripsikan dalam 5 tema terkait, yaitu : 1) Merasa tekanan berat, hancur, dan ngedrop ketika tahu status HIV positif, 2) Menerima status, memperoleh dukungan, dan bangkit, 3) Menjalani pengobatan dan berupaya tetap sehat, 4) Berhenti sebegai WPS dan menjalani kesempatan hidup kedua, 5) Jaga diri biar tidak tertular "Corona". Kelima tema tersebut dapat di interpretasikan bahwa makna pengalaman hidup WPS yang terinfeksi HIV adalah dari merasakan tekanan berat saat pertama kali terinfeksi HIV menuju peningkatan kualitas hidup yang lebih baik dalam menjalani aktivitas keseharinya setelah mampu menerima dirinya sebagai ODHA.

\section{DAFTAR PUSTAKA}

Carsita, W. N. (2017). Pengalaman ODHA dalam Menghadapi Stigma dan Diskriminasi Terkait Penyakitnya. The Indonesian Journal of Health Science, 8(2), 156-164. https://doi.org/http://dx.doi.org /10.32528/the.v8i2.869

Chenneville, T., Gabbidon, K., Hanson, P., \& Holyfield, C. (2020). The impact of COVID19 on HIV treatment and research: A call to action. International Journal of Environmental Research and Public Health, 17(12), 1-14. https://doi.org/10.3390/ijerph1 7124548

Ditjen P2P Kemenkes RI. (2019). Laporan Perkembangan HIVAIDS \& Penyakit Infeksi Menular Seksual (PMS) Triwulan II Tahun 2019. Jakarta: Kemenkes.

Gillard, A., \& Roark, M. F. (2013). Support for basic psychological needs in the context of HIV disclosure for older youth. Children and Youth Services Review, 35(1), 102-111.

https://doi.org/10.1016/j.childy outh.2012.10.021

Hargreaves, J. R., Busza, J., Mushati, P., Fearon, E., \& Cowan, F. M. (2017). Overlapping HIV and sex-work stigma among female sex workers recruited to 14 respondent-driven sampling surveys across Zimbabwe, 2013. AIDS Care Psychological and Socio- 
Medical Aspects of AIDS/HIV, 29(6), 675-685. https://doi.org/10.1080/095401 21.2016.1268673

Karamouzian, M., Akbari, M., Haghdoost, A., Hamidreza Setayesh, \& Zolala, F. (2014). "“ I Am Dead to Them ": HIV-related Stigma Experienced by People Living With HIV in. Journal of the Association of Nurses in AIDS Care, 26(1), 46-56. https://doi.org/10.1016/j.jana.2 014.04.005

Kartono, K. (2011). Patologi Sosial Kenakalan Remaja. Jakarta: Rajawali Perss.

Kemenkes. (2018). Infodatin Pusat Data dan Informasi Kementrian Kesehatan Republik Indonesia Situasi Umum HIV/AIDS dan Tes HIV. Retrieved from https://pusdatin.kemkes.go.id/r esources/download/pusdatin/in fodatin/InfoDatin-HIV-AIDS2018.pdf

Kemenkes. (2020). Pedoman Pencegahan dan Pengendalian Coronavirus Disesase (Covid19). Retrieved from https://www.kemkes.go.id/reso urces/download/infoterkini/COVID-19 dokumen resmi/REV04_Pedoman_P2_COVID-19_ 27 Maret2020_Tanpa TTD.pdf.pdf

Koentjoro. (2004). On The Spot, Tutur dari Sarang Pelacur. Yogyakarta: Cv.Qalam.

Kusuma, N. (2013). Konseling adherence untuk pengobatan infeksi HIV/AIDS : perlukah? In Global Medica and Health Communication. Global Medical and Health
Communication.

Leyva-Moral, J. M., de Dios Sánchez, R., Lluva-Castaño, A., \& Mestres-Camps, L. (2015). Living With Constant Suffering: A Different Life Following the Diagnosis of HIV. Journal of the Association of Nurses in AIDS Care, 26(5), 613-624. https://doi.org/10.1016/j.jana.2 015.04 .006

Nelson, E. U. E. (2019). The lived experience of violence and health-related risks among street sex workers in Uyo, Nigeria. Culture, Health and Sexuality, O(0), 1-14. https://doi.org/10.1080/136910 58.2019 .1648872

Nursalam, \& Kurniawati. (2009). Asuhan Keperawatan pada Pasien Terinfeksi HIV/AIDS. Jakarta: Salemba Medika.

Octavianty, L., Rahayu, A., Rosadi, D., \& Rahman, F. (2015). Pengetahuan, Sikap dan Pencegahan HIV/AIDS pada Ibu Rumah Tangga. Jurnal Kesehatan Masyarakat, 11(1), 53-59.

https://doi.org/https://doi.org/1 0.15294/kemas.v11i1.3464

Rahakbauw, N. (2016). Dukungan Keluarga Terhadap Kelangsungan Hidup ODHA (Orang dengan HIV/AIDS). Insani, 3(2), 64-82. Retrieved from stisipwiduri.ac.id

Shaluhiyah, Z., \& P, P. N. (2018). Respon Remaja Lelaki Suka Lelaki ( LSL ) dengan Status HIV Positif terhadap Pencegahan Penularan HIV kepada Pasangan. Jurnal Promosi Kesehatan Indonesia, 13(1).

Stutterheim, S. E., Sicking, L., Baas, 
I., Brands, R., Roberts, H., Brakel, V., ... Bos. (2016). Disclosure of HIV status to health care providers in the Netherlands: A qualitative Study. Journal of the Association of Nurses in AIDS Care, 27(4), 485-494. https://doi.org/doi.org/10.1016/ j.jana.2016.02.014

Thompson, J., Havenga, Y., \& Naude, S. (2015). The health literacy needs of women living with HIV/AIDS. Health SA Gesondheid, 20(1), 11-21. https://doi.org/10.1016/j.hsag.2 015.03.001

UNAIDS. (2019). UNAIDS DATA 2019. Retrieved from https://www.unaids.org/sites/de fault/files/media_asset/201707 20_Data_book_2017_en.pdf

UNAIDS. (2020). What People Living With HIV need to know about HIV and Covid-19. Retrieved from https://www.unaids.org/en/covi d19

World Health Organization. (2020). Pertanyaan dan jawaban terkait COVID-19, HIV dan antiretroviral di Indonesia. Retrieved from https://www.who.int/indonesia/ news/novel-coronavirus/qa-onhiv-and-antiretroviral 